\title{
Analisis PT Ultrajaya dalam Meningkatkan Produktivitas, Efisiensi dan Pendapatan
}

\author{
Mutiara Kamilatunnaimah ${ }^{1}$, Nadiya Nur Arafah ${ }^{2}$, Shevia $^{3}$, Stephanie ${ }^{4}$ \\ 1,2,3,4 Fakultas Ekonomi, Universitas Internasional Batam \\ 2041370.mutiara@uib.edu ${ }^{1 *}$
}

Received 23 Desember 2022| Revised 7 Januati 2022 | Accepted 30 Januari 2022

*Korespondensi Penulis

\begin{abstract}
Abstrak
Semua perusahaan yang menjalankan bisnis pastinya pernah menghadapi masalah yang bisa berdampak langsung bagi keberlangsungan hidup perusahaan. Oleh karena itu, perusahaan membutuhkan kebijakan dalam mengatasi masalah tersebut. Penelitian ini dilakukan bertujuan untuk menganalisis kebijakan yang dimiliki PT Ultrajaya dalam meningkatkan produktivitas, efisiensi, dan pendapatan perusahaannya. Penelitian ini menggunakan metode deskriptif dengan menganalisis sebuah permasalahan untuk dicari solusi penyelesaiannya. Teknik pengumpulan data dilakukan dengan materi data atau informasi melalui jurnal ilmiah, buku-buku referensi, dan bahan-bahan publikasi lainnya. Hasil dari penelitian ini adalah kebijakan yang diterapkan PT Ultrajaya dapat meningkatkan produktivitas, efisiensi, dan pendapatan perusahaan. Hal ini dibuktikan dengan prestasinya yang berhasil meningkatkan laba dan mempertahankan posisinya sebagai pemimpin pasar di industri minuman UHT.
\end{abstract}

Keywords: Ultrajaya; Produktivitas; Kebijakan; Pendapatan.

\begin{abstract}
All companies that run a business must have faced problems that could have a direct impact on the survival of the company. Therefore, companies need policies to overcome these problems. This study aims to analyze the policies owned by PT Ultrajaya in increasing the productivity, efficiency, and revenue of the company. This study uses a descriptive method by analyzing a problem to find a solution. Data collection techniques are carried out with data or information material through scientific journals, reference books, and other publication materials. The result of this research is that the policies implemented by PT Ultrajaya can increase productivity, efficiency, and company income. This is evidenced by his achievements in increasing profits and maintaining his position as the market leader in the UHT beverage industry.
\end{abstract}

Keywords: Ultrajaya; Productivity; Policy; Income.

\section{PENDAHULUAN}

Dalam menjalankan sebuah bisnis, perusahaan harus memperhatikan beberapa aspek, seperti memiliki perencanaan strategi untuk mempertahankan dunia persaingan dan melindungi kelangsungan bisnis kedepannya (Tika, Nurhasanah, Nurliyana, Andisfa, \& Putri, 2021). Perusahaan juga harus memiliki prinsip strategi dan kerja sama yang tepat agar permasalahan tidak mudah terjadi. Jika masalah sering terjadi, itu tandanya perusahaan masih belum matang dalam melaksanakan proses produksinya atau perusahaan masih belum siap secara maksimal. Oleh karena itu, tujuan jangka panjang dan perencanaan 
strategi harus mulai direncanakan sejak awal demi kepentingan perusahaan. Adapun salah satu perusahaan yang memegang teguh prinsip tersebut adalah PT Ultrajaya Milk Industri \& Trading Company Tbk.

Ultrajaya menggunakan sistem komputerisasi yang sudah terintegrasi, yaitu SAP, sejak tahun 2002. Bahkan Ultrajaya merupakan salah satu rujukan implementor SAP yang dinilai cukup sukses di dalam mengadopsi hampir semua modul SAP. Akan tetapi karena berbagai pertimbangan dan bisnis proses 2 yang semakin kompleks, akhirnya pada tahun 2012 mengganti sistem mereka ke Oracles EBS R.12 yang bisa membuat sistem terintegrasi dengan robot ASRS, suatu pencapaian yang sangat membanggakan bagi Ultrajaya. Sampai sekarang Project Oracle menjadi acuan untuk implementasi di anak - anak perusahaan Ultrajaya yang lain.

PT. Ultrajaya yang merupakan perusahaan minuman multinasional yang berpusat di Padalarang, Bandung Barat, Jawa Barat. Perusahaan ini terletak di Jalan Cimareme 131, Padalarang, Kabupaten Bandung. Awal mulanya perusahaan ini merupakan industri rumah tangga yang berdiri di tahun 1958, lalu berubah menjadi sebuah perseroan terbatas di tahun 1971. Di Indonesia, perusahaan ini merupakan pelopor di pasar minuman kemasan, dan saat ini memiliki beberapa teknologi pemrosesan tercanggih di kawasan ini.

PT. Ultrajaya membagi produk menjadi lima kategori. Pertama susu segar UHT. Kedua susu kental manis. Ketiga minuman teh UHT yaitu diwakili oleh Teh Kotak Melati. Keempat adalah minuman kesehatan UHT yang terdiri dari Sari Kacang Ijo dan Sari Asem Asli. Kelima adalah Kiyora yaitu merek teh kemasan. Selain itu Ultrajaya adalah perusahaan asli Bandung yang selalu melaksanakan CSR Desa Cimareme dan Desa Gadobangkong, Bandung Barat, karena dekat dengan perkantoran dan industri (PT ULTRAJAYA MILK INDUSTRY TBK, 2021a).

CSR adalah singkatan dari Corporate Social Responsibility dimana memiliki pengertian bahwa sebuah langkah atau aksi yang dilakukan oleh perusahaan sebagai komitmen dalam menjalankan bisnisnya. CSR dilaksanakan secara legal dan etis dengan tujuan untuk meningkatkan taraf kualitas hidup para karyawan beserta keluarganya serta berbagai komunitas, termasuk komunitas lokal dan komunitas luas (Nayenggita, Raharjo, \& Resnawaty, 2019). Perusahaan akan mendapatkan efek "domino" dalam artian positif, setelah mereka berhasil dalam menjalankan aksi CSR ini. Karena dengan adanya CSR yang dilakukan tersebut, negara akan menjadi lebih maju dan image perusahaan akan menjadi lebih baik di mata masyarakat. Selain itu, CSR juga akan memberikan keuntungan bagi lingkungan sekitar dengan membawakan banyak manfaat.

CSR oleh PT. Ultrajaya, yaitu dalam aspek pembangunan sosial dan masyarakat. Yang dipilih yaitu kepedulian terhadap Masyarakat sekitar PT. Ultrajaya berperan aktif dalam bidang kesehatan dengan membantu menyediakan peralatan medis ke puskesmas dan posyandu yang ada sesuai kebutuhan. PT. Ultrajaya memberikan dukungan dana untuk penyuluhan gizi dan kesehatan bagi Posyandu, yang diberikan kepada masyarakat secara bergilir. PT. Ultrajaya terus menawarkan dan mendistribusikan air bersih kepada warga di wilayah tersebut dengan membangun waduk air bersih, serta membantu penyediaan air bersih untuk rumah ibadah dan sekolah di wilayah tersebut. Selain itu, PT Ultrajaya juga berperan aktif dalam membangun pendidikan masyarakat Indonesia dengan cara memberikan bantuan berupa beasiswa, mengadakan seminar, dan membuat program renovasi serta pembangunan gedung sekolah. Biaya yang telah dikeluarkan oleh PT Ultrajaya per tahun 2014 untuk bidang pendidikan adalah sebesar Rp1.872.000.000 (PT ULTRAJAYA MILK INDUSTRY TBK, 2021b).

Seluruh hal ini tentu tidak lepas dari yang namanya proses bisnis. Proses bisnis adalah serangkaian operasi yang dimaksudkan untuk membantu organisasi mencapai tujuannya dan memberikan hasil yang telah ditentukan sebelumnya kepada konsumen. Selanjutnya, proses bisnis dapat digunakan untuk 
memecahkan masalah dalam perusahaan, dan proses bisnis dapat disesuaikan dengan kebutuhan perusahaan untuk memenuhi tujuannya. Proses bisnis dirancang untuk meningkatkan efisiensi dan daya saing sementara juga secara signifikan meningkatkan daya tanggap perusahaan agar sesuai dengan keinginan klien untuk setiap produk atau layanan yang dihasilkan dengan memberikan informasi waktu nyata yang dapat digunakan untuk mengidentifikasi dan menanggapi masalah. Itu terjadi secara tepat waktu dan tepat (PT ULTRAJAYA MILK INDUSTRY \& TRADING COMPANY Tbk, 2015)

Proses bisnis PT. Ultrajaya menghasilkan berbagai fungsi, termasuk penjualan dan pemasaran, manufaktur dan produksi, keuangan, sumber daya manusia, dan penelitian dan pengembangan. Menunjukkan kapasitas untuk menangkap setiap peluang yang muncul untuk kesuksesan dan kemajuan Perusahaan. PT. Ultrajaya telah melakukan pekerjaan yang sangat baik dalam menerapkan tata kelola perusahaan. Sebagai pemimpin pasar dalam bisnis minuman UHT, Perseroan akan terus berupaya mengikuti semua peraturan perundang-undangan, mematuhi peraturan bursa dan persyaratan peraturan dalam pelaksanaan tata kelola perusahaan yang baik. Menurut (PT ULTRAJAYA MILK INDUSTRY \& TRADING COMPANY Tbk, 2018), berikut proses bisnis PT. Ultrajaya :

1. Fungsi Penjualan dan Pemasaran, bertujuan:menjual produk dengan kualitas terbaik. Aktivitas Proses Bisnis yag dilakukan meliputi: a) Identifikasi kebutuhan dan keinginan pelanggan; b) Melakukan survei ke berbagai kalangan untuk mengetahui kebutuhan dan keinginan; c) Melakukan creative marketing, membuat iklan di media sosial, memasang iklan di stasiun tv, membuat billboard, dan mengadakan promosi ke sekolah-sekolah; dan d) Pemasaran didistribusikan ke seluruh Indonesia dan juga diekspor ke berbagai negara

2. Fungsi Manufaktur dan Produksi, berujuan menghasilkan produk yang berkualitas. Kegiatan proses bisnis meliputi: a) Mengambil bahan bakunya (susu sapi segar) lalu dinginkan pada suhu $4{ }^{\circ} \mathrm{C}$ agar bakteri tidak mudah berkembang biak; dan b) Mengolah bahan mentah menjadi produk jadi 3. Melakukan proses pengemasan di ruang steril.

3. Fungsi Keuangan, bertujuan mengelola keuangan perusahaan. Kegiatan proses bisnis meliputi: a) Pengelolaan kas atau kas untuk distribusi gaji, tagihan listrik, kreditur, kewajiban lancar, pemeliharaan stok, pembelian bahan baku, dll; dan b) Menganalisis rasio, peramalan keuangan, pengendalian biaya dll.

4. Fungsi Sumber Daya Manusia, bertujuan mengelola SDM organisasi. Kegiatan proses bisnis meliputi: a) Kompensasi atau penetapan gaji pegawai sesuai dengan bagian dan tugas masing-masing pegawai; b) Menempatkan karyawan sesuai dengan kemampuannya; dan c) Melakukan program pelatihan.

5. Fungsi Penelitian dan Pengembangan Penelitian, bertujuanmengelola dan mengembangkan bisnis dengan aktivitas bisnis: a) Mengembangkan teknologi UHT (Ultra High Temperature) untuk kemasan antiseptic; dan b) Mengembangkan laboratorium untuk memastikan bahan baku hingga produk jadi tetap steril.

Dalam upaya mempertahankan pangsa pasar produk minuman UHT dan memaksimalkan keuntungan, Perseroan memiliki beberapa kebijakan terkait seperti perusahaan selalu terlibat dalam mengembangkan pengakuan publik atas merek dagang yang dimilikinya karena percaya bahwa pengakuan tersebut adalah kunci untuk mencapai pertumbuhan bisnis. Perusahaan dan anak perusahaan memiliki jaringan distribusi yang luas yang tidak hanya mencakup pulau Jawa, tetapi juga mencakup pulau-pulau besar Indonesia lainnya. Untuk itu kami melakukan analisis kebijakan yang digunakan PT. Ultrajaya dalam meningkatkan produktivitas, efisiensi dan pendapatan (PRYADI, 2012).

\section{METODE}


Penelitian ini menggunakan pendekatan kualitatif dengan metode penelitian yang digunakan adalah metode penelitian deskriptif. Metode analisis deskriptif kualitatif yaitu suatu metode penelitian yang dilakukan untuk menggambarkan proses atau peristiwa yang sedang berlaku pada saat ini di lapangan yang dijadikan objek penelitian, kemudian data atau informasinya dianalisis sehingga diperoleh suatu pemecahan masalah. Teknik pengumpulan data yang dilakukan dengan materi data atau informasi melalui jurnal ilmiah, bukubuku referensi, dan bahan-bahan publikasi lainnya.

\section{HASIL DAN PEMBAHASAN}

Dalam melakukan kegiatan operasionalnya, perseroan dipengaruhi dan dihadapkan kepada kendala usaha dan risiko keuangan yang antara lain adalah :

\section{Risiko nilai tukar mata uang}

Risiko nilai tukar mata uang Rupiah terhadap mata uang asing, khususnya terhadap mata uang Dollar Amerika, timbul dari transaksi pembelian bahan baku, penjualan, dan pinjaman dalam mata uang asing. Nilai tukar Rupiah sering terdepresiasi sehingga mengakibatkan meningkatnya harga beli bahan-bahan baku impor, padahal seiring dengan pertumbuhan usaha, kebutuhan Perseroan terhadap bahan baku juga meningkat, termasuk kebutuhan akan bahan baku impor. Untuk mengurangi risiko tersebut Perseroan senantiasa memantau fluktuasi mata uang asing dan seluruh pinjaman bank dan hutang berupa Medium Term Note (MTN) dilakukan dengan menggunakan mata uang Rupiah (PT Ultrajaya Milk Industri, 2019).

\section{Risiko kredit}

Perseroan mempunyai risiko kredit yang terutama sekali berasal dari piutang dagang dan simpanan di bank. Untuk risiko kredit yang berasal dari piutang dagang kepada pelanggan Perseroan mempunyai kebijakan untuk memastikan bahwa penjualan hanya dilakukan kepada pelanggan yang memiliki riwayat kredit yang baik. Selain itu umur piutang terus dipantau dan dianalisa untuk tidak terjadi kredit macet. Risiko kredit yang berasal dari simpanan di bank Perseroan mengelolanya antara lain dengan memonitor reputasi dan kapitalisasi bank_(PT Ultrajaya Milk Industri, 2018).

\section{Pasokan bahan baku}

Pasokan bahan baku yang diperlukan Perseroan sangat bergantung kepada para pemasok, baik pemasok lokal maupun pemasok luar. Perseroan tidak bisa menjamin bahwa para pemasok bahan baku ini dapat mempertahankan pasokan yang konsisten dalam memenuhi kebutuhan Perseroan, sekarang dan yang akan datang. Perseroan juga tidak bisa menjamin bahwa kualitas bahan yang dikirimkan para pemasok ini akan selalu sesuai dengan kualitas yang disyaratkan Perseroan. Oleh karena itu Perseroan harus tetap menjaga agar produksi tidak terganggu oleh kelangkaan atau kekurangan pasokan bahan baku (PT Ultrajaya Milk Industri, 2016).

\section{Persaingan usaha}

Kondisi perekonomian Indonesia yang relatif stabil telah meningkatkan tingkat kesejahteraan masyarakat sehingga menyebabkan permintaan akan barang- barang konsumsi (consumer goods) meningkat tajam. Hal ini telah mengakibatkan munculnya investor- investor dan produsen-produsen baru di bidang industri makanan dan minuman, khususnya di sektor industri minuman UHT. Selain itu, terbukanya pintu pasar global mengakibatkan semakin bervariasinya produk-produk minuman UHT ex import yang beredar di pasar. Hal-hal ini menuntut perseroan untuk terus berinovasi agar tetap bisa bersaing di pasar. Pada saat 
ini, perseroan perlu memiliki pembeda sebagai sebuah ciri khas (differentiation) agar bisa menonjol di pasaran dan bisa bersaing dengan pesaing lainnya (Luqiana \& Prabowo, 2021).

\section{Pasokan listrik}

Pasokan listrik dari PLN masih sering mengalami gangguan sehingga dapat mengganggu jalannya proses produksi yang pada akhirnya dapat menyebabkan kekurangan pasokan produk-produk Perseroan di pasar (PT Ultrajaya Milk Industri, 2017).

Selain itu, Tahun 2020 juga menjadi tantangan bagi bisnis Perseroan dalam usaha memenuhi tujuan yang telah ditetapkan. Inisiatif yang pemerintah buat untuk memerangi pandemi virus Corona (Covid-19) telah memperlambat perkembangan nasional ke level terendah dalam beberapa tahun, mempengaruhi kebiasaan konsumsi dan daya beli masyarakat. Di tengah perlambatan pertumbuhan ekonomi nasional dan persaingan pasar yang ketat, Penjualan Bersih Perseroan turun sebanyak 4,1 persen, yang awalnya Rp 6,22 triliun pada 2019 mnjadi Rp 5,97 triliun pada 2020. Tetapi karena Perseroan mampu meningkatkan laba tahun berjalan sebesar 7,1 persen, dari Rp1,04 triliun pada 2019 menjadi Rp1,11 triliun pada 2020, berkat kebijakan atau rencana yang efektif dan tepat yang kami jalankan. Pencapaian ini merupakan buah dari usaha dan kerja keras seluruh aspek dalam lingkungan perusahaan, yang berkolaborasi untuk menjalankan seluruh kebijakan Perseroan yang telah ditetapkan oleh Direksi, guna mengatasi segala tantangan yang kita hadapi.

Dalam menghadapi permasalahan bisnis, PT Ultrajaya memiliki kebijakan strategis tahun yang terlampir pada data perusahaan tahun 2020 didasarkan pada pengembangan dan penyempurnaan strategi tahun sebelumnya. Perusahaan masih berupaya untuk meningkatkan jangkauan pasar dan tidak hanya di Jawa, tetapi juga di pulau-pulau dan wilayah penting lainnya di Indonesia, terdapat jaringan distribusi. Perseroan menambah berbagai depoo di seluruh Jawa untuk menanggapi peritel modern seperti hypermart, supermarket, dan minimarket. Di luar Pulau Jawa, Perseroan terus memupuk, mempertahankan, juga memperkuat hubungan dengan seluruh biro atau distributor yang berada di kota-kota besar Indonesia.

Perusahaan melakukan riset pasar secara berkala untuk mendapatkan wawasan dan mempersiapkan barangbarang bermutu tinggi dan disukai pelanggan.

Untuk menjamin ketersediaan dan kesinambungan pasokan bahan baku dalam negeri yang berkualitas tinggi, Perseroan menjalin hubungan kerja yang erat dengan peternak dan hewan lokal, serta pemasok.

Perusahaan menggunakan proses produksi otomatis yang meminimalkan campur tangan manusia, dan kontrol kualitas dilakukan secara ketat di semua tahap produksi, dari penerimaan bahan baku hingga penyimpanan barang yang sudah jadi (PT ULTRAJAYA MILK INDUSTRY \& TRADING COMPANY, 2020).

Program tanggung jawab sosial PT. Ultrajaya merupakan implementasi dari komitmen perusahaan untuk membangun kapasitas serta memberikan kesempatan bagi masyarakat untuk berkembang dan memperoleh peluang yang lebih berkualitas. PT. Ultrajaya berupaya menggerakan Indonesia melalui empat dimensi yaitu Lingkungan hidup, ketenagakerjaan, pengembangan sosial dan kemasyarakatan, tanggung jawab produk.

Salah satu bentuk kepedulian dari PT. Ultrajaya dalam bidang pengembangan sosial dan kemasyarakatan khususnya terhadap kepedulian kepada masyarakat yaitu di desa Cimareme dan desa Gadobangkong dengan cara berperan aktif di bidang kesehatan dengan memberikan bantuan berupa alatalat kesehatan yang diperlukan oleh puskesmas dan posyandu yang ada di desa-desa tersebut. PT. Ultrajaya juga memberikan bantuan dana untuk penyuluhan tentang kecukupan gizi dan kesehatan masyarakat bagi petugaspetugas posyandu. Dan saat ini PT. Ultrajaya masih menyediakan dan menyalurkan air bersih 
kepada masyarakat yang berdomisili di sekitar perseroan dengan membuat bak-bak penampungan air bersih dan perseroan membantu memberikan air bersih untuk rumah-rumah ibadah dan juga sekolahsekolah yang berada di sekitarnya. Hal ini dapat dilihat melalui "Indeks Pembangunan Manusia Kabupaten Bandung Barat dari tahun 2010-2016" khususnya di kecamatan Padalarang.

\section{SIMPULAN}

Proses bisnis adalah serangkaian tindakan atau metode kegiatan yang dimaksudkan untuk membantu organisasi atau perusahaan mencapai tujuan strategisnya dengan menghasilkan produk atau hasil yang terukur dan terencana untuk konsumen internal dan eksternal. Proses bisnis juga dapat digunakan untuk memecahkan masalah dalam perusahaan, dan dapat disesuaikan dengan kebutuhan perusahaan untuk memenuhi tujuannya.

Sebagai perusahaan yang telah beroperasi lebih dari empat puluh tahun, perusahaan telah menunjukkan kemampuan yang baik. Sasaran yang ditentukan telah berhasil dilewati, strategi yang dibuat telah dijalankan dengan baik dan telah melewati kendala yang ditemui. Dan Perseroan telah berhasil meningkatkan laba dan mempertahankan posisinya sebagai pemimpin pasar di industri minuman UHT. Perolehan ini menggambarkan baik komitmen Direksi Perseroan untuk terus memajukan produktivitas setiap tahunnya maupun upaya Perseroan untuk mengupayakan efisiensi di segala aspek.

\section{Ucapan Terima Kasih}

Terima kasih yang sebesar-besarnya disampaikankepada Bapak Dr. Ir, Nasar Buntu L, S.T., M.M. selaku dosen pembimbing kami yang dengan sabar memberikan banyak ilmu, pengarahan dan dukungan kepada kami untuk menyelesaikan artikel serta rekan sekelompok yang sudah bekerja sama dengan sangat baik untuk menyelesaikan artikel ini.

\section{DAFTAR PUSTAKA}

Luqiana, A. N., \& Prabowo, B. (2021). Pengaruh Citra Merek, Harga, Dan Kualitas Produk Terhadap Loyalitas Pelanggan Pada Pembelian Susu Ultra. Jurnal Revolusi Indonesia, 1(6), 454.

Nayenggita, G. B., Raharjo, S. T., \& Resnawaty, R. (2019). Praktik Corporate Social Responsibility (Csr) Di Indonesia. Focus : Jurnal Pekerjaan Sosial, 2(1), 61. Https://Doi.Org/10.24198/Focus.V2i1.23119

Pryadi, R. G. (2012). Pengaruh Motivasi Dan Disiplin Kerja Terhadap Produktivitas Kerja Karyawan Bagian Gudang Di Pt Ultrajaya Milk Industry And Trading Company Tbk.

Pt Ultrajaya Milk Industri. (2016). Annual Report.

Pt Ultrajaya Milk Industri. (2017). Laporan Tahunan.

Pt Ultrajaya Milk Industri. (2018). Laporan Tahunan.

Pt Ultrajaya Milk Industri. (2019). Annual Report.

Pt Ultrajaya Milk Industry \& Trading Company, T. (2020). Laporan Tahunan 2020 Annual Report. Retrieved From Http://Www.Ultrajaya.Co.Id/Uploads/Ultj-Ar-2020.Pdf

Pt Ultrajaya Milk Industry \& Trading Company Tbk. (2015). Laporan Tahunan 2015. Retrieved From Http://Www.Ultrajaya.Co.Id/Uploads/Ultrajayaar2015final.Pdf

Pt Ultrajaya Milk Industry \& Trading Company Tbk. (2018). Presentasi Perusahaan Pt Ultrajaya.

Pt Ultrajaya Milk Industry Tbk. (2021a). Annual Report. Retrieved From Https://Www.Ultrajaya.Co.Id/Investor-Relation/Annual-Report/Eng

Pt Ultrajaya Milk Industry Tbk. (2021b). Csr. Retrieved From Https://Www.Ultrajaya.Co.Id/Csr/Eng Tika, D. R. S., Nurhasanah, F., Nurliyana, Andisfa, R., \& Putri, A. M. (2021). Strategi Pemasaran Pt . 
Ultrajaya Milik Industry \& Trading Company. 5, 2896-2903. Retrieved From Https://Jptam.Org/Index.Php/Jptam/Article/View/1316/1159 